discussion papers

FS IV $97-18$
WISSENSCHAFTSZENTRUM BERLIN FÜR SOZIALFORSCHUNG

SOCIAL SCIENCE RESEARCH CENTER BERLIN

Risk Sharing in the Supplier Relationship:

New Evidence from the Japanese

Automotive Industry

Hiroyuki Okamuro

Hitotsubashi University

September 1997

ISSN Nr. 0722 - 6748

Forschungsschwerpunkt Marktprozeß und Unternehmensentwicklung

Research Area

Market Processes and Corporate Development 
Zitierweise/Citation:

Hiroyuki Okamuro, Risk Sharing in the Supplier Relationship: New Evidence from the Japanese Automotive Industry, Discussion Paper FS IV 97 - 18, Wissenschaftszentrum Berlin, 1997.

Wissenschaftszentrum Berlin für Sozialforschung gGmbH, Reichpietschufer 50, 10785 Berlin, Tel. (030) 25491 - 0 


\title{
ABSTRACT
}

\section{Risk Sharing in the Supplier Relationship: \\ New Evidence from the Japanese Automotive Industry}

\author{
by Hiroyuki Okamuro*
}

The Japanese corporate system is assumed to contain an implicit insurance mechanism in various aspects. This paper proves the existence of risk sharing mechanism in supplier relations in a different way from the previous studies, using a unique data set of Japanese automotive parts suppliers. The results suggest that the auto makers absorb a part of the business risk of the suppliers, in spite of recent structural changes in the supplier system: The relative stability of their profit rate is significantly influenced by the intensity of business relations.

\section{ZUSAMMENFASSUNG}

\section{Risikoteilung in der Zulieferbeziehung: Neue Befunde aus der japanischen Automobilindustrie}

Vom japanischen Unternehmenssystem wird oft angenommen, daß es einen impliziten Versicherungsmechanismus mit verschiedenen Aspekten enthält. In diesem Aufsatz wird mit einer von den bisherigen Forschungen verschiedenen Methode überprüft, ob in der Zulieferbeziehung, hier speziell für die Automobilindustrie, ein Mechanismus für Risikoteilung besteht. Die Ergebnisse weisen darauf hin, daß die Automobilhersteller trotz struktureller Veränderungen im Zuliefersystem in letzter Zeit geschäftliche Risiken der Zulieferer zum Teil selber tragen: Die relative Stabilität ihrer Profitrate wird signifikant beeinflußt von der Intensität der Zulieferbeziehung.

This paper is based on my previous paper (Okamuro 1995), providing new evidence using a different data set with new variables. I thank the participants of the economic seminar at the WZB on 24. April 1997 for helpful comments and suggestions. I am also grateful to Miyako Iitsuka and Naoko Seshimo for their assistance in additional data collection from Japan. 


\section{Risk Sharing in the Japanese Corporate System}

The Japanese corporate system is characterized by generally long-term relationships in various aspects: Many large corporations have quite stable ownership structure through interlocking shareholding as well as long-term relations with their main banks, suppliers, and employees. According to the implicit contract theory, stable long-term relations make it possible for business partners to arrange implicitly flexible terms of trade to stabilize price and business performance (cf. Ito/Matsui 1989). In this sense, the Japanese corporate system is often assumed to include an insurance or risk sharing mechanism through long-term relations. ${ }^{1}$

Aoki (1984a, 1988) argues the insurance mechanism in supplier relations as follows: If there is a difference in the degree of risk aversion between the business partners, it is more efficient as a whole that higher risk is taken by the less risk-averse firm in return for a higher risk premium, i.e., for a greater share of the common rent made by an efficient risk sharing between the business partners. ${ }^{2}$ In supplier relations in Japan, it may be assumed that, in general, big assemblers have a greater risk-bearing capability than smaller suppliers because of their relatively higher degree of diversification and stronger financial power. Thus, it will be efficient that big assemblers take a greater part of the business risk for a risk premium. It means that the assemblers get a greater profit share in return for insuring their suppliers against profit fluctuation. Therefore, even if the profit rate of the assemblers exceeds that of the suppliers for a long time, it may be the result of risk sharing as an implicit contract rather than evidence for the exploitation of suppliers.

Figure 1 compares the profit rate of 11 car makers (average value) with that of the automotive parts suppliers in Japan. It is clear that the profit rate of the suppliers is continuously higher and more stable than that of the car makers. It seems to indicate that a part of business risk of the former is absorbed by the latter, though the level of risk premium to be paid seems to be quite low, if any.

The results of the previous empirical studies [Kawasaki/McMillan (1987), Asanuma/Kikutani (1992)] seem to support the idea of risk absorption, but we hesitate to accept it readily because of some problems in the research method, as we will discuss later. So it is the purpose of this paper to examine in an alternative way if the Japanese

1 Empirical analysis on this topic shows different results. While Nakatani (1984) and Osano/Tsutsui (1986) provide evidence for the insurance function of the main bank, Horiuchi/Packer/Fukuda (1988) does not support this view. Nakatani's further argument (1984) for risk sharing in corporate groups through a mutual insurance mechanism is not supported by Odagiri (1992). To risk sharing mechanism in corporate groups cf. further Sheard (1989), (1991), and (1994).

2 For the mathematical proof of this theorem see Aoki (1984b). 
supplier relationship involves an insurance mechanism for suppliers, i.e., if the assemblers absorb a part of business risk of their suppliers.

The Japanese supplier system, as well as the corporate system as a whole, has been undergoing a structural change since the late 1980s. Big assemblers are restructuring their supplier relations among others by intensive exploitation of new purchasing sources including overseas suppliers. Suppliers, on the other hand, have increased the ratio of direct sales to the final market and the number of customers, thus reducing the dependence on the main customer. ${ }^{3}$ Such a "flexibilization" of the supplier system may weaken risk sharing, if any, while globalization of economic activities and increasing importance of $R \& D$ under rapidly changing market conditions are supposed to enhance business risk in general. So it would be of great interest to examine with recent data if risk absorption by the customer is in function in spite of these structural changes.

The next section provides a critical survey of the previous empirical studies on risk sharing in supplier relations. In Section 3 the existence of risk sharing will be proved in an alternative way using a unique firm-level data set from the Japanese automobile industry. Concluding remarks follow in Section 4.

\section{Critical Survey of the Previous Empirical Studies}

Kawasaki and McMillan (1987) attempted the first econometric analysis of risk sharing in supplier relations based on principal agent theory, taking the practices of price adjustment during the contract term in the Japanese automotive industry, as described in Asanuma (1984), into consideration. They used industry level data in the period 19731982 to prove 1) to what extent big assemblers bear the risk of production costs fluctuation of subcontractors (small and medium sized firms in the industry sectors with a high ratio of subcontractors), and 2) which factors determine the ratio of risk absorption by the assemblers. In their study the ratio of risk absorption $\alpha$ by customers was formulated as follows:

$\alpha=1-(\mathrm{S} / \sigma)$, where $\mathrm{S}$ and $\sigma$ are standard deviations of profit and production costs (of a supplying industry) respectively.

According to the "Whitebook of Small Business" (Chusho Kigyocho 1997), the dependence of suppliers on their main customer, measured by the concentration of sales, decreased clearly from 1987 to 1996 (the estimated average ratio of sales to the main customer is $70 \%$ and 55\% respectively). For recent structural changes in the Japanese supplier relations see also Keizai Kikakucho 1996, p. 243 ff., and Kokumin Kin'yu Koko 1996, Part 2. 
If the profit of a supplying industry is completely influenced by any fluctuation of cost, or in other words, if the buyers do not accept any adjustment of purchasing price to changes of production cost, $\alpha$ is assumed to be equal to 0 and so all the risk of cost fluctuation is taken by the supplier. This case corresponds to the fixed price contract. On the other hand, if the cost fluctuation does not influence the profit at all, or in other words, if any fluctuation of cost is shifted to the purchasing price, $\alpha$ is assumed to be equal to 1 and so all the risk of the cost fluctuation is absorbed by the buyer. This case corresponds to the cost-plus contract. ${ }^{4}$

The estimated values of $\alpha$ in 5 firm size classes of 9 industry sectors are distributed between 0.39 and 0.89 , and the majority of the values are over 0.5 , with an unweighted average of 0.69 . This result suggests, according to the authors, that contracts with suppliers are designed more like a cost-plus contract rather than a fixed price contract, so that the buyers bear more than half of the risk of cost fluctuation of the suppliers. They furthermore found that the purchasing price reacts more sensitively to the cost fluctuation of suppliers (i.e., the value of $\alpha$ is higher), 1) the more risk averse the suppliers are, 2) the bigger the cost fluctuation is, and 3) the less serious the problem of moral hazard is (in this case this means the risk for buyers that suppliers declare a higher cost than it really is, taking advantage of the lack of information on the side of buyers).

While Kawasaki and McMillan (1987) analyze aggregated data from industry statistics, Asanuma and Kikutani (1992) use firm level data for the period 1977-1987 to test risk sharing in the automotive industry in Japan with the same method as the former. Their study shows interesting results that the average value of the estimated risk absorption ratio $\alpha$ is over 0.9 for all groups of car makers. The regression analysis on the influence factors of the value of $\alpha$ for each auto maker's supplier group provides results which mostly correspond to those of Kawasaki and McMillan (1987).

Can we just conclude from their results that the Japanese automotive manufacturers absorb over $90 \%$ of the business risk of parts suppliers? And can we reject with their results the possibility that auto makers shift risk to parts suppliers?

We hesitate to accept readily the estimation results in these studies because of some serious problems in the estimation method. Furthermore, even if it is proved that car makers absorb the risk of cost fluctuation of parts suppliers, it does not exclude the possibility that at the same time the former shift the risk of demand fluctuation to parts

In this model they do not take quantitative changes of demand into account, as Asanuma and Kikutani (1992) remark. This limitation induces serious problems in the estimation of risk absorption, as we will discuss later. 
suppliers, as the traditional hypothesis remarks. Now let us explain this critique in more detail.

It is a most serious problem in the estimation of the risk absorption ratio that we cannot distinguish the unit cost from the total cost because of the restriction of data. In the estimation period, the production of parts and the purchase of raw materials increased remarkably and almost continuously, along with the production of cars. In this case, even if there is no change in the unit price of raw materials, the standard deviation of production costs gets bigger as total cost increases. Thus the fluctuation of production costs will be overestimated. In fact, through the 1980s, total cost, along with sales, increased sharply, though the price of raw materials went down slightly according to the input price index.

Secondly, the value of $\alpha$ is clearly influenced by the level of the profit rate. If the profit rate (the ratio of operating income to sales) is at some percent, as is usually the case in reality, the amount of cost is, by definition, more than ten times bigger than that of profit. Suppose both total profit and total cost increase to the same extent in proportion to sales because of increasing demand, while there is no change in the unit price of parts. Then the standard deviation of cost will be more than ten times bigger than that of profit, so the ratio of risk absorption exceeds 0.9 in this example, though there is no risk absorption at all. The estimated ratio will be the higher, the lower the profit rate is. ${ }^{5}$

Thirdly, we assume that production costs and profit increase and decrease rather in the same direction, when we take the fact of derived demand into consideration. In the previous studies it is implicitly assumed that the price of raw materials is an exogenous variable, but in fact it can be influenced by demand fluctuations. Thus, there can also be the following sequence of causality: ${ }^{6}$ A decrease in the demand for cars leads to a decrease in demand for auto parts, which further induces a decrease in demand for raw materials, which finally causes a drop in materials prices. In this case the decrease in the profit of suppliers and the drop in materials prices will occur at the same time, contrary to the assumption of the risk absorption hypothesis. In the previous studies the fluctuations of costs and profits are measured by their standard deviations, where the

5 This may explain why the estimated ratio of risk absorption in Asanuma/Kikutani (1992) is much higher than that in Kawasaki/ McMillan (1987). The former calculate the profit rate as the ratio of operating income to sales, while the latter measure it as the price-cost margin, which is much higher than the other.

$6 \quad$ Yamazaki (1994) points out in his study on risk sharing in the construction sector that the price of construction materials and labour costs are rather endogenous variables and so are influenced by the fluctuation of demand for, and unit price of, the construction. 
direction of changes does not matter, so that we cannot preclude the suspicion that the risk sharing would not have been properly estimated.

Moreover, the previous studies completely ignore the risk of demand fluctuation, which may be substantial for suppliers, as they assume that there is no quantitative change of demand during the period. So they reject the hypothesis of risk shifting in regard to demand fluctuation without considering this kind of risk at all.

Let us now estimate, as a trial, the ratio of risk shifting from auto makers to suppliers in regard to demand fluctuation, applying the method of Kawasaki and McMillan (1987). Here the risk shifting ratio $\beta$ is formulated as follows: $\beta=1-\left(S^{*} / \sigma^{*}\right)$, where $S^{*}$ and $\sigma^{*}$ are standard deviations of profit and sales of auto makers respectively. If the demand (sales) for cars fluctuates remarkably while there is almost no change in the profit, the value of $\beta$ is close to 1 , meaning that auto makers shift most of the risk of demand fluctuation to suppliers. The estimated values of $\beta$ for the 11 car makers in the same period as Asanuma and Kikutani (1992) are between 0.91 and 0.98, suggesting that auto makers shift the largest part of the risk of demand fluctuation to suppliers (or to dealers), even to a higher extent than they absorb from suppliers the risk of cost fluctuation. Since the input price index in the automotive industry remained very stable over the last 10 years, whereas the demand fluctuation was at a quite high level, this result would further mean that the auto makers bear the rather less important kind of risk of the suppliers, while shifting to them the more essential one.

In our view, however, such a high ratio of risk shifting does not reflect the reality, but is supposedly due to an enormous difference between the total amount of profit and sales, as discussed above. Anyway, this trial shows how difficult and dangerous it is to measure risk sharing in this way.

Now it would be obvious that the examination of risk sharing in the previous studies has serious problems. Furthermore, it was proved that they provide no evidence to reject the traditional view of risk shifting, since they do not consider at all the risk of demand fluctuation, which may be essential for parts suppliers. For a more proper analysis of risk sharing in business relations, we need to avoid the above-mentioned problems and to take the risk of demand fluctuation appropriately into account.

In the next section we will prove the existence of risk sharing in supplier relations in an alternative way. 


\section{Empirical Analysis of Risk Sharing}

\section{(1) Analytical Method and Model}

An alternative way to prove the existence of risk sharing in the supplier relationship is to test if the relative stability of the profit rate of suppliers, which is regarded as the measure of risk absorption by customers, differs significantly according to the intensity of business relations. Hereby we assume that, other things being equal, the customers can and will absorb risk of the suppliers the more, the closer the business relations with them is, as we argue later in more detail. Therefore, if the relative stability of the profit rate of suppliers depends on the business intensity with the customers, it will be an evidence for risk absorption by the customer. ${ }^{7}$ Moreover, we will put into the model some variables for risk aversion of suppliers as well to control those for business intensity and to see if the profit stability also depends on the degree of risk aversion, as the risk absorption hypothesis suggests.

Our method, which is related to that applied in Nakatani (1984) and Odagiri (1992) to test the insurance function of corporate groups in Japan, is not based on principal-agent theory, as it ignores an essential kind of risk for the suppliers, namely the risk of demand fluctuation. An advantage of our rather simple way is that it is able to prove risk sharing as a whole, regardless of the kind of risk. In this way the problems of estimating risk absorption, as observed in the previous studies, can be avoided.

As mentioned above, we assume that the extent of risk absorption by the customer depends on the intensity of business relations, especially when the risk of demand fluctuation matters. A car maker can absorb the risk of his suppliers the more, the higher his weight in the total sales of a supplier is. He will also be the more ready to insure a supplier against profit fluctuation, the closer their business relationship is, to keep the supplier capable of innovation and further customer-specific investments, and not to lose his own specific investment for the supplier through its closure or bankruptcy (we will come back to this argument later again). And the supplier will be in need of risk absorption the more, the higher his dependence on the main buyer is, as his possibility to disperse the risk will be less.

Now let us come to explain the variables in the model (An overview of the variables is shown in the Appendix): The dependent variable STD is standard deviation of annual

$7 \quad$ We should take into account the possibility of the supplier to disperse the risk by himself through diversification as well, as will be discussed later. 
profit rates (the ratio of operating income to sales ${ }^{8}$ ) in the period 1985-1994, which indicates the extent of fluctuation of the profit rates. It should be controlled by APR, the average profit rate in the period, to estimate the relative stability of the profit rate. ${ }^{9}$

We have three variables for risk aversion of suppliers. LNLAB is the log-transformed value of the average number of employees during the period, and is a proxy for firm size. ${ }^{10}$ Both Kawasaki/McMillan (1987) and Asanuma/ Kikutani (1992) found that, the bigger a supplier is in size, the lower is the degree of his absolute risk aversion. It may also be understood intuitively that a firm will be less risk-averse, the lower the weight of a project relative to firm size is. The other variables for risk aversion are LNCAP, logtransformed value of the average equity capital in million yen during the period, and CAPR, the ratio of equity capital to total asset. They can be regarded as indicators of the firm's resistance to financial difficulties. So it is assumed that a firm is the less riskaverse, the higher the amount of equity capital and its proportion to total asset is. These variables will be used alternatively.

Business intensity with the main customer is measured by some variables: 1) the proportion of sales to the main buyer to whole sales (MBR), ${ }^{11}$ 2) the proportion of the stocks held by the main buyer to the total stocks (SHR), or alternatively 3) a dummy variable for affiliation, taking 1 if the main buyer holds at least $25 \%$ of total shares of the supplier and 0 otherwise ${ }^{12}$ (SH25), and 4) a dummy variable for procurement of

8 We use the ratio of operating profit to sales as the measure, because it reflects directly the results of business transactions and is not disturbed by financial transactions.

9 We can use variance, standard deviation and coefficient of variation to measure the extent of fluctuation. Since the level of standard deviation can be influenced by the level of the average value, in general it is desirable to use, when the averages differ remarkably from each other, the coefficient of variation to compare the extent of fluctuation. However, in the analysis of the profit rate, the average value can be negative or near to zero, which gives rise to difficulties. Therefore we will use in this paper the standard deviation controlled by the average value.

10 The number of employees as well as the amount of equity capital are logarithmic transformed to bring data distribution closer to normal distribution.

11 This variable is used as a dummy variable for risk aversion in Asanuma/Kikutani (1992). They argue that, if the suppliers are aware of risk absorption by the main customer, they will be the more dependent on him, the more risk-averse they are. But we may as well argue as follows, wenn we take the problem of moral hazard into account as they do: If the suppliers know there is such an insurance, those who are highly dependent on the main buyer may become less risk-averse. Then we may rather assume a negative correlation between the degree of risk aversion and the dependence on the main customer. So we are rather critical of regarding the sales dependence on the main buyer as a proxy for risk aversion.

12 This dummy variable is used since the percentage of shareholding by the main buyer is not normally distributed, as many firms have no or little capital relationship with the main buyer. A firm is regarded as affiliated with another one, if at least $25 \%$ of shares is held by him. 
materials, taking 1 if the main buyer or a trading company in his group mostly provides the supplier with raw materials and 0 otherwise (SOURCE). ${ }^{13}$ Moreover, to examine the effect of changing business intensity, we include variables MBRCH (change in MBR from 1985 to 1994) and SHRCH (change in SHR from 1985 to 1994) in the model.

The other variables are a dummy variable for direct business with a car maker (or for being a first-tier supplier to him), taking 1 if the main buyer is a car maker and 0 otherwise (FIRST) and a customer-specific dummy variable taking 1 if Toyota is the steady main buyer and 0 otherwise (TOYOTA). This variable is added to prove if Toyota, the top car maker in Japan with clearly better and more stable business performance than the others, ${ }^{14}$ absorb a higher extent of risk from the suppliers than his rivals do.

Our hypotheses in regard to the effect on the profit stability (or fluctuation) are as follows:

At first, all of the coefficients of the variables for risk aversion should have positive signs, if the customer absorbs risk of suppliers in proportion to their risk aversion, as the previous studies indicate.

In regard to business intensity, we assume that the car makers absorb the risk of their suppliers in proportion to the intensity of business relations with them. Then, other things being equal, the profit rate of the suppliers will be the more stable, the larger part of sales is concentrated on the main buyer and the larger part of shares is held by him. The procurement of raw materials by the main buyer will also stabilize the profit rate of the suppliers, as in this case the partnership will be especially intensive because of the bilateral customer-supplier-relations and because the main buyer has another effective instrument for profit stabilization of suppliers. So far the signs of the coefficient of MBR, SHR, SH25 and SOURCE are all expected to be negative.

However, suppliers may also be able to disperse business risk through diversification, and there may be a certain degree of sales dependence on the main buyer under which risk dispersion through diversification overcompensates for a shortage of risk absorption by the business partner. In this case, the curve of profit fluctuation will be convex upwards; the fluctuation of the profit rate will increase to a certain point along with the

13 Asanuma and Kikutani (1992) use this variable as a proxy for moral hazard, assuming that the problem of moral hazard of the suppliers (over-reporting the increase of material price) is less severe, if the main buyer provides them with materials.

14 The profit rate (the ratio of operating income to sales) of Toyota from 1985 to 1994 is $3.9 \%$ on the average, while the average value of all the Japanese auto makers in the same period is $1.3 \%$; The coefficient of variation is for Toyota 0.536 and for all the auto makers 1.092, indicating that Toyota shows a more stable performance than the others. 
sales dependence on the main buyer and then decrease continuously. Then the coefficients of MBR and MBR2 (MBR-square) will have a positive and a negative sign respectively.

We further assume that decreasing business intensity, or in other words the "flexibilization" of the business relationship, will result in weakening risk absorption by the customer. So far the signs of coefficients of MBRCH and SHRCH are expected to be negative. However, if the efforts of suppliers to disperse risk through diversification are successful enough to compensate for the loss of risk absorption, decreasing business intensity will not necessarily lead to more fluctuation of the profit rate. In this sense the coefficient of MBRCH can have positive or negative sign.

We can expect the profit rate of the suppliers which have direct business with auto makers (first-tier firms) to be more stable than that of the lower-tier firms, in the assumption that the auto makers have a higher capability of risk absorption and so absorb more risk than the suppliers do. Therefore, the sign of the coefficient of FIRST is assumed to be negative. As for the variable TOYOTA, the coefficient is expected to be negative as well, for he is able to absorb more risk of suppliers than his rivals because of his good performance and strong financial power.

\section{(2) Data Source and Data Set}

We use a data set at the firm level for the analysis. Our data sources are "Kaisha Nenkan" (Annual Corporation Reports for Listed Companies) and "Kaisha Sokan" (Annual Corporation Reports for Unlisted Companies) published by Nihon Keizai Shinbunsha, which provide annual financial data, as well as "Nihon no Jidosha Buhin Kogyo" (Yearbook of the Japanese Auto Parts Industry) edited by JAPIA (Japanese Auto Parts Industry Association) which provides data on business relations of a part of the member firms such as the name of the main customers with the percentage of sales for each of them and the name of the main stockholders with the percentage of stockholding by each of them. Combining these two data sources we can get a unique data set which enables us to carry out an empirical analysis of risk sharing in the supplier relationship.

Our sample consists of 69 suppliers $^{15}$ to car makers which report their annual financial data in the period 1985-1994 (fiscal years) and the data on business relations with their

15 From originally 70 sample firms 1 had to be removed as an outlier in regard to the dependent variable. In the following regression analysis, further outliers in regard to MBRCH and SHRCH will be removed. 
main customers for the beginning and the end of this period. We excluded from the sample those who went through mergers and acquisitions during the period to avoid possible deterrence. Since the sample firms have different settlement terms, and many firms changed them during the period, we adjusted the financial data to the settlement term in March for all sample firms.

Sample characteristics are summarized in Table 1. Among the sample firms, 39 (57\%) are listed companies at the end of the period. Firm size (average value of 1985 and 1994) varies from 192 to 10.200 employees (1.720 on the average) and from 5 to 415 billion yen in annual sales (59 billion on the average). Moreover, most firms (64) are first-tier suppliers (including 20 Toyota- and 20 Nissan-suppliers) in the sense that their steady main buyer is an auto maker. Thus, we cannot deny that the sample is biased towards the upper group and large corporations because of the restricted availability of data.

Only 5 firms (7\%) changed the main buyer during the period of 10 years, and in 4 cases of them, it was no more than a slight change in the sales percentage between the two biggest customers. The average sales ratio to the main buyer remained during the period as stable (from $52.5 \%$ in 1985 to $51.2 \%$ in 1994) as the average ratio of stock held by the main buyer (from $21.3 \%$ in 1985 to $21.8 \%$ in 1994), with 53 suppliers (77\%) partly financed by the main customer. 26 firms $(38 \%)$ obtain production materials mostly from the main buyer or a trading company affiliated with him. So the business relation with the main customer may be regarded as quite strong and stable for the sample firms.

Figure 2 shows the profit rate of 69 sample firms in the period 1985-1994 in comparison to that of 11 car makers. It demonstrates that the former achieved on the average higher and more stable profit rates than the latter. ${ }^{16}$ A similar trend can be seen in Figures 3 and 4 in regard to Toyota and Nissan with their suppliers, though Toyota achieved higher profit rates than his suppliers during the boom years.

\section{(3) Estimation Results}

Table 2 shows the results of the regression analysis. Sample size varies between 66 and 68 as 1 and 2 outliers were removed in regard to the variables MBRCH and SHRCH respectively. It is to note that the results did not get better by the removal of the outliers. Moreover, we substituted SH25 for SHR as the result was always better with SH25 than

16 Only 6 firms in the sample have a loss at least in one fiscal year in the period, and 3 firms in 2 or more years. The latter have a negative average profit rate in the period as well and so can be regarded as being in financial difficulties. 
with the other. The variable SOURCE could not be included in the equation together with shareholding variables and TOYOTA because of the multicollinearity problem.

All the variables of risk aversion are always negatively correlated with profit fluctuation, though hardly significant. It suggests, contrary to the argument of the risk absorption hypothesis, that the main buyer absorbs risk to a higher extent from less risk-averse suppliers. This result may also imply that large suppliers with a high level of equity capital can stabilize their profit rates somehow.

The estimated values of all the variables of business relations have expected signs except for those of SHRCH and are significant except for those of FIRST. The coefficients of MBR-square are all negative and significant, while MBR have positive and significant ones, which suggests that the relative fluctuation (stability) of the profit rate increases (decreases) to a certain point along with increasing sales dependence on the main buyer and then decreases (increases) continuously. It can be estimated that the profit fluctuation is at the highest when the ratio of sales to the main buyer is around $50 \%(48.5 \sim 51.8 \%) .{ }^{17}$ Without MBR-square, the coefficients of MBR are negative but not significant, which is not shown in Table 2. MBRCH has negative and significant (though weakly) coefficients, suggesting that decrease of the sales dependence on the main buyer increases the fluctuation of the profit rate.

As for the variables of shareholding by the main buyer, the effect of $\mathrm{SH} 25$ is negative as expected, but weaker compared to the sales dependence. The coefficients of SHRCH are, different from our expectation, significantly positive. ${ }^{18}$ Direct business with a car maker does not reduce the profit fluctuation significantly, while Toyota stabilizes the profit rate of his suppliers to a higher extent than the other car makers. Finally, procurement of the production materials from the main buyer increases the profit stability.

These results suggest as a whole that the Japanese car makers absorb a part of the business risk of their suppliers depending on the intensity of business relationship with them, in spite of structural and strategic changes in the supplier system in recent years. The closeness of business relationship with the main buyer explains a quarter of the profit stability (or instability) of the suppliers, as Equation 4 shows.

17 It means that the standard deviation of the profit rate of a supplier which is totally dependent on a single customer is about 0.006 less than that of a supplier which concentrates $50 \%$ of the sales on the main buyer, other things being equal. This effect is not trivial as the standard deviation is 0.011 on the average of the sample firms.

18 This result could be interpreted as an effect of reverse causality, i.e., that the main buyer intensified financial support for those suppliers which show relative instability of business performance. 


\section{Concluding Remarks}

The purpose of this paper was to prove the existence of risk sharing in the recent Japanese supplier relationship under structural and strategic changes, in a different way from the previous studies which show serious estimation problems.

In this paper we tested if the relative stability of the profit rate of suppliers is significantly influenced by business intensity. The main findings are as follows: 1) The extent of dependence on the main buyer in regard to the ratio of sales influences significantly the stability of the profit rate; it decreases to a certain point with increasing dependence on the main buyer and then increases; 2) Affiliation with the main buyer as well contributes to stabilize the profit rate, though the effect is weaker compared to sales dependence; 3 ) Also firm size and the ratio and amount of equity capital are factors which stabilize the profit rate, though often not significantly; It suggests that risk aversion of the suppliers is not an important factor of risk absorption. 4) The factors of business intensity and trade patterns determine together at most a quarter of the profit fluctuation. So the car makers absorb only a part of business risk of the suppliers.

These results imply as a whole risk absorption by the car makers and support in this respect the risk absorption hypothesis in the previous studies. However, contrary to this hypothesis, according to which the risk absorption by the main buyer depends on the risk aversion of the suppliers, in our analysis business intensity is the main factor for risk absorption.

Our results suggests that the risk absorption is provided to the suppliers selectively. It is also intuitively acceptable that the car makers, trying to build up efficient business relations with the suppliers while selecting the superior ones continuously, provide for the stabilization of corporate performance of the selected firms with which they have intensive relations. Our results are in this respect also consistent with the traditional view that the main buyers actively bring up and support the selected suppliers.

Some limitations in our analysis should be remarked explicitly. Firstly, the sample consists of relatively small numbers of firms and large "upper-class" suppliers are overrepresented. Therefore it would be dangerous to generalize our results directly to smaller firms. Secondly, as far as unlisted companies are concerned, the sample includes only those which report their financial data voluntarily. So the profit rate of suppliers may be overestimated and financial crisis underestimated, as those with poor performance would 
not be eager to show it publicly. ${ }^{19}$ Thirdly, our analysis is limited to the automotive industry, so one should be careful in applying them to other industries. Finally, our attention was concentrated on the role of the main buyer in the assumption that he plays a decisive role in the risk sharing, if any, and also because exact data on the other customers are not always available. So the role of the other customers remains unexplained.

To finish this paper, we will point out some remaining questions. Firstly, a puzzle remains why larger firms or those with a higher level of equity capital, i.e. those with less risk aversion, show more stability in the profit rate. Another interesting puzzle is why the ratio of sales to the main buyer is actually concentrated on the middle range (about $50 \%$ on the average) in the sample, where they can rather expect a higher fluctuation of the profit rate. Maybe there are other advantages of "taking the golden mean" which would compensate for the relative loss of risk absorption by the customer. Finally, we are still confronted with the question why Japanese car makers are willing to stabilize the profit rate of their suppliers, while allowing them a higher profit rate on the average. Aoki's idea of the insurance in return for a risk premium seems to apply only to Toyota among the car makers (see Figure 3), whereas the case of Nissan (Figure 4) is really puzzling. Our preliminary answer is that, as mentioned above briefly, the car makers want to keep their suppliers capable of innovations and further customer-specific investments which are of great importance for their future development, and avoid losing their own specific investments in their suppliers through closure or bankruptcy.

19 As mentioned before, only 6 firms in the sample had a loss at least in one fiscal year in the period. In fact, we found suppliers which gave up reporting financial data in the Annual Corporation Report after one or two terms with loss and so could not be included in the sample. 


\section{References}

Aoki, Masahiko (1984a), "Innovative Adaptation through the Quasi-tree Structure: An Emerging Aspect of Japanese Enterpreneurship", Zeitschrift für Nationalökonomie (Suppl.), pp. 177-198.

---- (1984b), "Risk Sharing in the Corporate Group", in: Aoki, M. (ed.), The Economic Analysis of the Japanese Firm, Amsterdam/New York/Oxford (North-Holland), pp. 259-264.

---- (1988), Information, Incentives and Bargaining in the Japanese Economy, Cambridge Univ. Press.

Asanuma, Banri (1984), "Nihon ni okeru Buhin Torihiki no Kozo: Jidosha Sangyo no Jirei" [The Structure of the Parts Trade in Japan: A Case Study of the Automobile Industry], Keizai Ronso (Kyoto Univ.) 133-3, pp. 137-158.

Asanuma, B./T. Kikutani (1992), "Risk Absorption in Japanese Subcontracting: A Microeconometric Study of the Automobile Industry", The Journal of the Japanese and International Economies 6, pp. 1-29.

Chusho Kigyo Cho [Small Business Agency] (ed.)(1997), Chusho Kigyo Hakusho [Whitebook of Small Business] for 1997, Tokyo.

Horiuchi, A./F. Packer/S. Fukuda (1988), "What Role Has the 'Main Bank' Played in Japan?", Journal of the Japanese and International Economies 2, pp. 159-180.

Ito, M./A. Matsui (1989), "Kigyo: Nihon teki Torihiki Keitai" [Firm: Japanese Patterns of Transaction], in: Ito, M./K. Nishimura (eds.), Oyo Mikuro Keizaigaku [Applied Microeconomics], Tokyo (University of Tokyo Press), pp. 19-53.

Kawasaki, S./J. McMillan (1987), "The Design of Contracts: Evidence from Japanese Subcontracting", Journal of the Japanese and International Economies 1, pp. 327-349.

Keizai Kikaku Cho [Economic Planning Agency] (ed.)(1996), Keizai Hakusho [Whitebook of the Japanese Economy] for 1996, Tokyo.

Kokumin Kin'yu Koko Sogo Kenkyusho [Research Institute of People's Finance Corporation] (ed.)(1996), Shinka suru Shitauke Kigyo [Evolution of Subcontractors], Tokyo.

Nakatani, Iwao (1984), "The Economic Role of Financial Corporate Grouping" in: Aoki, M. (ed.), The Economic Analysis of the Japanese Firm, Amsterdam/New York/Oxford (North-Holland), pp. 227-258. 
Odagiri, Hiroyuki (1992), Growth through Competition, Competition through Growth: Strategic Management and the Economy in Japan, Oxford Univ.Press.

Okamuro, Hiroyuki (1995), "Changing Subcontracting Relations and Risk-Sharing in Japan: An Econometric Analysis of the Automobile Industry", Hitotsubashi Journal of Economics 36, pp. 207-218.

Osano, H./Y. Tsutsui (1986), "Credit Rationing and Implicit Contract Theory", International Journal of Industrial Organization 4, pp. 419-438.

Sheard, Paul (1989), "The Japanese General Trading Company as an Aspect of Interfirm Risk-Sharing", Journal of the Japanese and International Economies 3, pp. 308-322.

---- (1991), "The Role of Firm Organization in the Adjustment of a Declining Industry in Japan: The Case of Alminium", Journal of the Japanese and International Economies 5, pp. 14-40.

---- (1994), "Interlocking Shareholdings and Corporate Governance" in: Aoki, M./R. Dore (eds.), The Japanese Firm. Sources of Competitive Strength, Oxford (Clarendon Press), pp. 310-349.

Yamazaki, Fukuhisa (1994), "Kensetsugyo ni okeru Motouke Shitauke no Risuku Shearingu ni tsuite" [on the Risk Sharing between the General Constractors and Subcontractors in the Construction Sector], Jochi Keizai Ronshu 40-1, pp. 35-45.

\section{Data Sources}

Nihon Keizai Shinbunsha (ed.), Kaisha Nenkan [Annual Corporation Reports for Listed Companies], various years.

---- Kaisha Sokan [Annual Corporation Reports for Unlisted Companies], various years.

Nihon Jidosha Buhin Kogyokai (JAPIA) (ed.), Nihon no Jidosha Buhin Kogyo [The Auto Parts Industry in Japan], various years.

Ministry of Finance, Hojin Kigyo Tokei Nenpo [Annual Financial Statements of Incorporated Businesses], various years. 


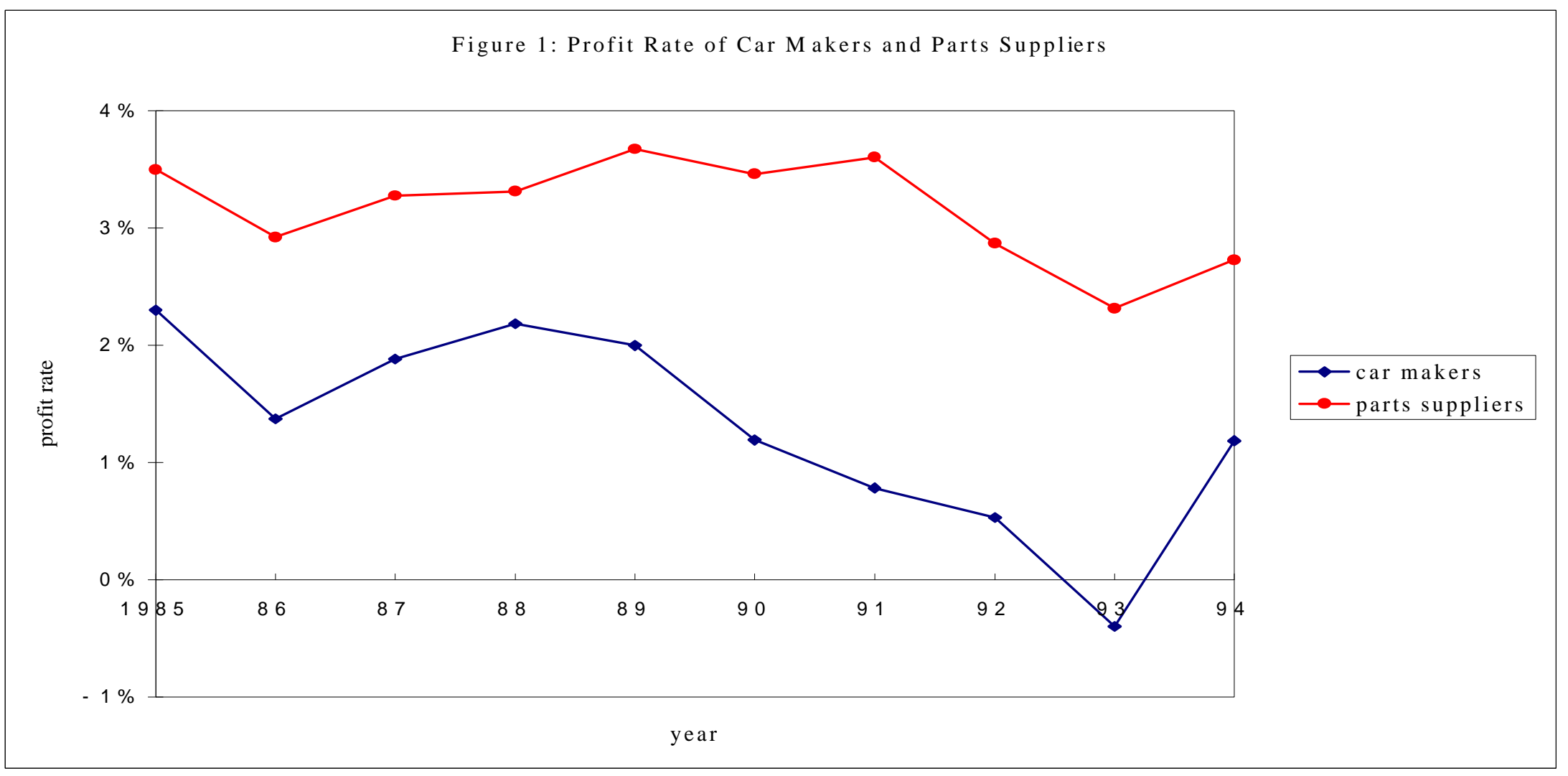

notes:

1) profit rate: the ratio of operating income to sales

2) car makers: unweighted average value of all the 11 manufacturers

3) parts suppliers: all corporations in the transportation equipment industry with less than 1 billion yen share capital

data sources: Ministry of Finance, Hojin Kigyo Tokei Nenpo, verious years and

Nihon Keizai Shinbunsha, Kaisha Nenkan, various years 


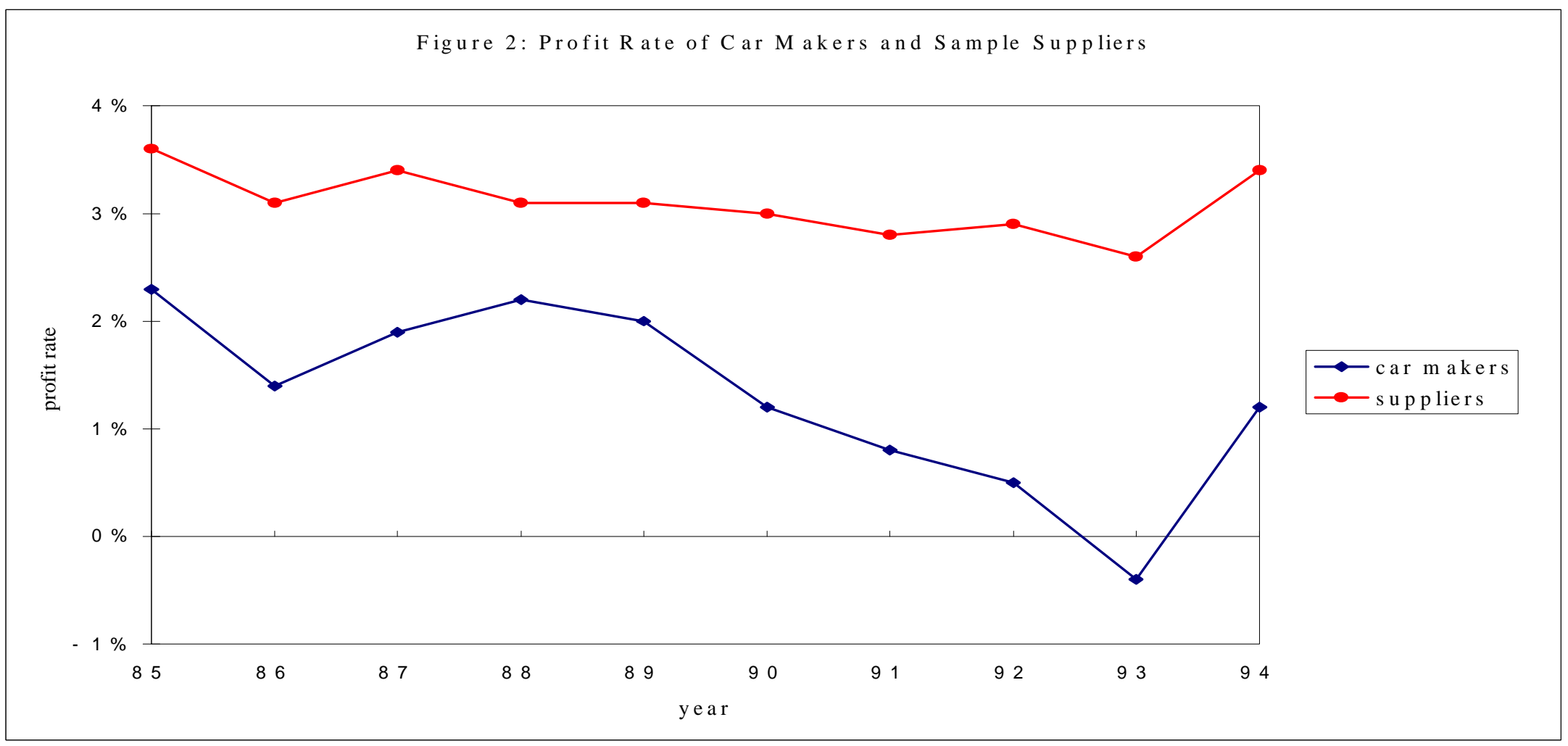

notes:

1) profit rate: the ratio of operating income to sales

2) car markers: unweighted average value of all the 11 manufacturers

3) parts suppliers: unweighted average value of 69 suppliers in the sample

data sources: Nihon Keizai Shinbunsha, Kaisha Nenkan, various years; Kaisha Sokan, various years 


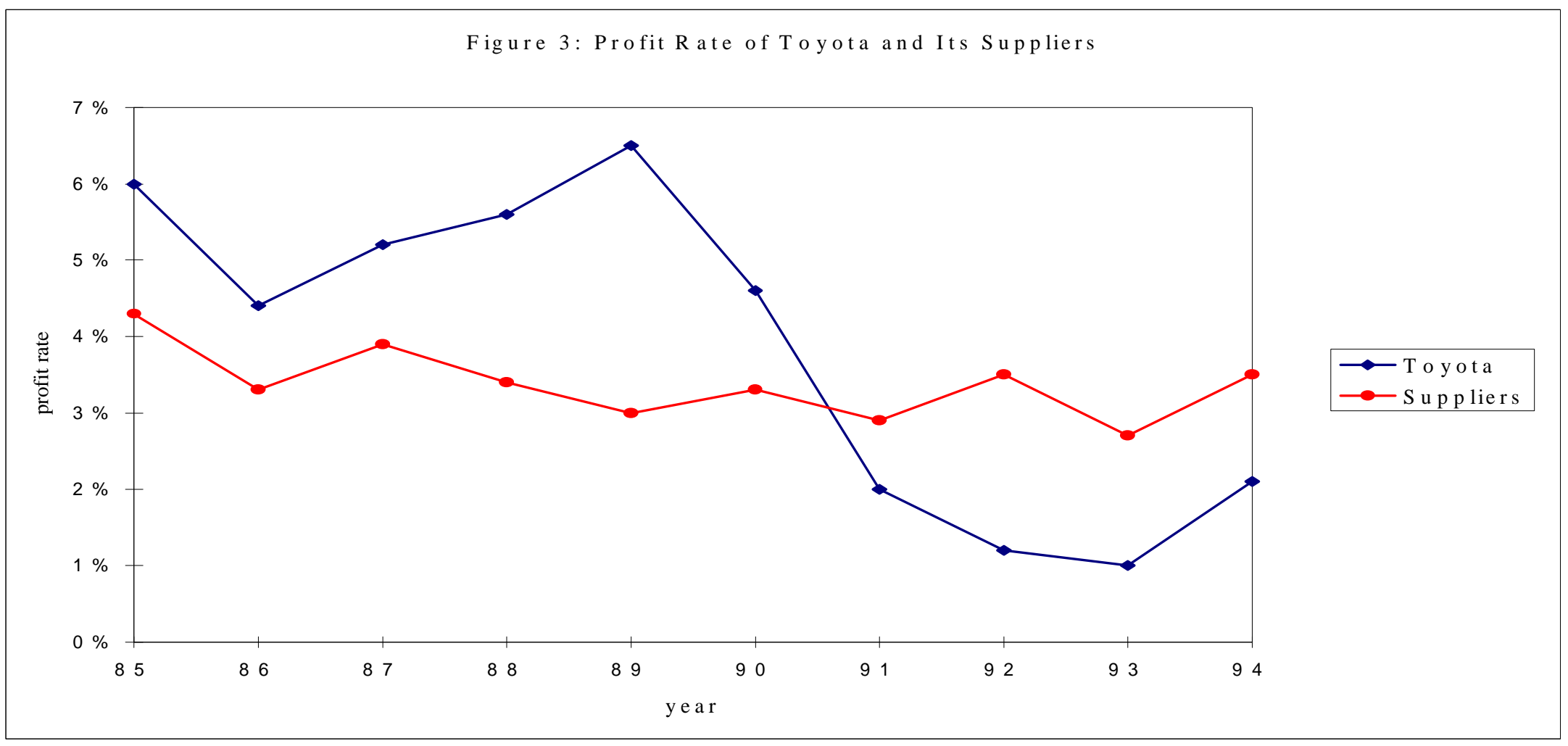

notes:

1) profit rate: the ratio of operating income to sales

2) suppliers: unweighted average value of 20 sample firms for whom Toyota is the steady main buyer during the period

data sources: Nihon Keizai Shinbunsha, Kaisha Nenkan, various years; Kaisha Sokan, various years 


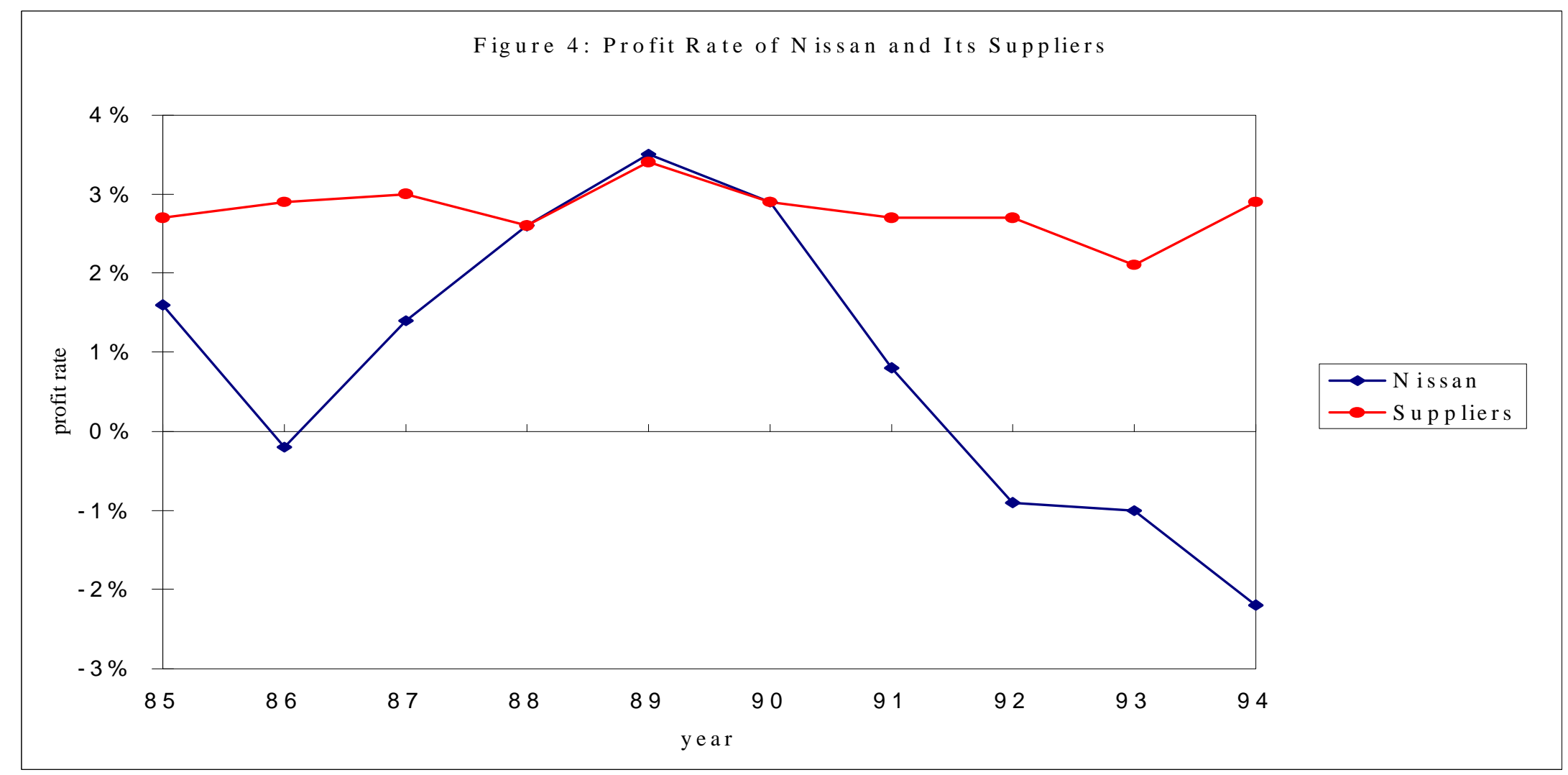

notes:

1) profit rate: the ratio of operating income to sales

2) suppliers: unweighted average value of 20 sample firms for whom Nissan is the steady main buyer during the period

data sources: Nihon Keizai Shinbunsha, Kaisha Nenkan, various years; Kaisha Sokan, various year 
Table 1: Sample Characteristics (Data Distribution)

\begin{tabular}{|l|c|c|c|c|c||}
\hline variables* & AVERAGE & STDEV $^{1)}$ & MAX & MIN & MEDIAN \\
\hline average profit rate & 0.031 & 0.020 & 0.089 & -0.009 & 0.025 \\
\hline STDEV profit rate & 0.011 & 0.005 & 0.025 & 0.003 & 0.011 \\
\hline average employees & 1,720 & 1,675 & 10,200 & 192 & 1,222 \\
\hline average sales $^{2)}$ & 59,197 & 63,469 & 415,017 & 5,194 & 40,007 \\
\hline average equity cap. $^{2)}$ & 15,886 & 22,525 & 160,098 & 203 & 10,167 \\
\hline equity capital ratio $^{3)}$ & 0.357 & 0.161 & 0.695 & 0.053 & 0.376 \\
\hline sales ratio to MB $^{4)}$ & 0.518 & 0.238 & 0.980 & 0.030 & 0.511 \\
\hline sales ratio change $^{5)}$ & -0.013 & 0.101 & 0.463 & -0.319 & -0.008 \\
\hline shares held by MB & 0.215 & 0.204 & 1.000 & 0.000 & 0.207 \\
\hline shareholding change & 0.005 & 0.050 & 0.232 & -0.098 & 0.000 \\
\hline \hline
\end{tabular}

Notes:

1) standard deviation

2) in million yen

3) the ratio of equity capital to total asset (CAPR)

4) the ratio of sales to the main buyer to total sales (MBR)

5) changes in the ratio of sales to the main buyer and the ratio of shares held by the main buyer from 1985 to 1994 respectively (MBRCH, SHRCH)

* See Appendix for the explanation of the variables. 
Table 2: Estimation Results on the Fluctuation of Profit Rates

\begin{tabular}{|c|c|c|c|c|c|c|}
\hline variables & (1) & (2) & (3) & (4) & (5) & (6) \\
\hline const. & $\begin{array}{c}0.0145 \mathrm{a} \\
(2.745)\end{array}$ & $\begin{array}{c}0.0124 \mathrm{~b} \\
(2.656)\end{array}$ & $\begin{array}{c}0.0095 \mathrm{a} \\
(3.104)\end{array}$ & $\begin{array}{c}0.0089 \mathrm{a} \\
(2.892)\end{array}$ & $\begin{array}{c}0.0102 \mathrm{a} \\
(3.300)\end{array}$ & $\begin{array}{c}0.0205 \mathrm{a} \\
(3.939)\end{array}$ \\
\hline A P R & $\begin{array}{l}0.0321 \\
(1.115)\end{array}$ & $\begin{array}{l}0.0446 \\
(1.514)\end{array}$ & $\begin{array}{c}0.0674 \mathrm{c} \\
(1.985)\end{array}$ & $\begin{array}{l}0.0377 \\
(1.318)\end{array}$ & $\begin{array}{l}0.0303 \\
(1.037)\end{array}$ & $\begin{array}{c}0.0064 \\
(0.219)\end{array}$ \\
\hline L N L A B & $\begin{array}{l}-0.0885 \\
(-1.300)\end{array}$ & & & & & $\begin{array}{c}-0.0017 \mathrm{~b} \\
(-2.472)\end{array}$ \\
\hline L N C AP & & $\begin{array}{l}-0.0481 \\
(-0.991)\end{array}$ & & & & \\
\hline C A P R & & & $\begin{array}{l}-0.0074 \\
(-1.576)\end{array}$ & & & \\
\hline M B R & $\begin{array}{l}0.0288 \mathrm{a} \\
(2.731)\end{array}$ & $\begin{array}{l}0.0285 \mathrm{a} \\
(2.680)\end{array}$ & $\begin{array}{l}0.0292 \mathrm{a} \\
(2.790)\end{array}$ & $\begin{array}{c}0.0268 \mathrm{~b} \\
(2.551)\end{array}$ & $\begin{array}{l}0.0229 \mathrm{~b} \\
(2.153)\end{array}$ & $\begin{array}{c}0.0201 \mathrm{c} \\
(1.860)\end{array}$ \\
\hline M B R 2 & $\begin{array}{l}-0.0279 \mathrm{a} \\
(-2.915)\end{array}$ & $\begin{array}{l}-0.0279 \mathrm{a} \\
(-2.870)\end{array}$ & $\begin{array}{l}-0.0290 \mathrm{a} \\
(-3.027)\end{array}$ & $\begin{array}{l}-0.0258 \mathrm{a} \\
(-2.720)\end{array}$ & $\begin{array}{l}-0.0236 b \\
(-2.429)\end{array}$ & $\begin{array}{l}-0.0205 b \\
(-2.034)\end{array}$ \\
\hline M B R C H & $\begin{array}{l}-0.0130 \mathrm{c} \\
(-1.900)\end{array}$ & $\begin{array}{c}-0.0133 c \\
(-1.931)\end{array}$ & $\begin{array}{c}-0.0126 c \\
(-1.855)\end{array}$ & $\begin{array}{c}-0.0130 \mathrm{c} \\
(-1.892)\end{array}$ & $\begin{array}{c}-0.0175 b \\
(-2.596)\end{array}$ & $\begin{array}{c}-0.0114 \\
(-1.640)\end{array}$ \\
\hline S H 25 & $\begin{array}{l}-0.0020 \\
(-1.534)\end{array}$ & $\begin{array}{l}-0.0022 c \\
(-1.673)\end{array}$ & $\begin{array}{c}-0.0022 \mathrm{c} \\
(-1.693)\end{array}$ & $\begin{array}{l}-0.0023 c \\
(-1.750)\end{array}$ & $\begin{array}{l}-0.0020 \\
(-1.504)\end{array}$ & \\
\hline S H R C H & $\begin{array}{l}0.0364 \mathrm{~b} \\
(2.253)\end{array}$ & $\begin{array}{l}0.0360 \mathrm{~b} \\
(2.204)\end{array}$ & $\begin{array}{c}0.0346 \mathrm{~b} \\
(2.142)\end{array}$ & $\begin{array}{c}0.0383 \mathrm{~b} \\
(2.370)\end{array}$ & $\begin{array}{l}0.0309 \mathrm{c} \\
(1.901)\end{array}$ & \\
\hline F I R S T & $\begin{array}{c}-0.0028 \\
(-1.352)\end{array}$ & $\begin{array}{c}-0.0028 \\
(-1.351)\end{array}$ & $\begin{array}{l}-0.0025 \\
(-1.219)\end{array}$ & $\begin{array}{c}-0.0031 \\
(-1.508)\end{array}$ & $\begin{array}{l}-0.0041 \mathrm{c} \\
(-1.977)\end{array}$ & \\
\hline TOYOTA & $\begin{array}{l}-0.0025 \mathrm{c} \\
(-1.833)\end{array}$ & $\begin{array}{c}-0.0024 c \\
(-1.722)\end{array}$ & $\begin{array}{c}-0.0018 \\
(-1.214) \\
\end{array}$ & $\begin{array}{c}-0.0029 b \\
(-2.121)\end{array}$ & & \\
\hline SOURCE & & & & & & $\begin{array}{c}-0.0024 c \\
(-1.793)\end{array}$ \\
\hline $\operatorname{adj} . R 2$ & 0.259 & 0.250 & 0.269 & 0.250 & 0.205 & 0.170 \\
\hline F-value & 3.525 & 3.405 & 3.659 & 3.709 & 3.392 & 3.294 \\
\hline $\mathrm{n}$ & 66 & 66 & 66 & 66 & 66 & 68 \\
\hline
\end{tabular}

Notes: 1) t-statistics in parentheses a: significant at $1 \%$ level b: significant at $5 \%$ level c: significant at $10 \%$ level

2) Sample size $n$ varies according to the number of outliers.

3) See appendix to the explanation of the variables in the table. 
Appendix: Explanation of Independent Variables

1) APR: average profit rate (ratio of operating profit to sales) in the period 1985-1994 (adjusted to the fiscal year)

2) LNLAB: log-transformed number of employees; average value of the fiscal years 1985 and 1994

3) LNCAP: log-transformed book value of equity capital in million yen; average value of the fiscal years 1985 and 1994

4) CAPR: the ratio of equity capital to total asset; average value of the fiscal years 1985 and 1994

5) MBR: the ratio of sales to the main buyer (the customer with the highest share in the sales of the supplier in the fiscal year 1985) to total sales; average value of the fiscal years 1985 and 1994

6) MBR2: square of MBR

7) MBRCH: change in MBR from 1985 to 1994 (the value in 1994 minus the value in 1985)

8) SHR: the ratio of shares held by the main buyer to total shares; average value of the fiscal years 1985 and 1994

9) SH25: dummy variable for affiliation; taking 1 if SHR is 0.25 or more and 0 otherwise

10) SHRCH: change in SHR from 1985 to 1994 (the value in 1994 minus the value in 1985)

11) FIRST: dummy variable for first-tier suppliers; taking 1 if the main buyer is a car maker both in 1985 and 1994 and 0 otherwise

12) TOYOTA: dummy variable for Toyota; taking 1 if the main buyer is Toyota both in 1985 and 1994 and 0 otherwise

13) SOURCE: dummy variable for material procurement; taking 1 if the production materials are provided chiefly by the main buyer or a trade company affiliated with him in 1994 and 0 otherwise 